\title{
MENINGKATKAN HASIL BELAJAR BAHASA INDONESIA MATERI MENULIS SURAT UNDANGAN KELAS 5 SD MUHAMMADIYAH 2 DEPOK MENGGUNAKAN METODE MODELLING THE WAY BERBANTU MEDIA AUDIO VISUAL
}

\author{
Wahyu Bagja Sulfemi, \\ STKIP Muhammadiyah Bogor \\ Wahyubagja@Gmail.Com \\ Bayinah \\ SD Muhammadiyah 2 Depok \\ Bayafiah@gmail.com
}

\begin{abstract}
Abstrak : Penelitian Tindakan Kelas (PTK) dilaksanakan dalam dua siklus pada peserta didik kelas V SD Muhammadiyah 2 Depok sebanyak 27 peserta didik terdiri dari Laki-laki 24 dan perempuan 13. PTK ini bertujuan untuk meningkatkan motivasi, minat, dan hasil Belajar Bahasa Indonesia. Dalam pembelajaran Prasiklus diperoleh hasil rata-rata peserta didik 56,67, terdapat 10 orang peserta didik mencapai KKM atau $37 \%$. Hasil pengamatan guru terhadap peserta didik yang dapat menjawab pertanyaan guru hanya 7 peserta didik, atau sebesar $26 \%$. Siklus 1 diperoleh rata-rata nilai 66,67 yang mencapai KKM 17 orang atau $63 \%$. Berdasarkan data pengamatan guru terhadap peserta didik yang dapat menjawab pertanyaan berjumlah 15 peserta didik atau 56\%. Siklus 2 diperoleh rata-rata nilai 86,30 dan semua peserta didik sudah mencapai KKM. Berdasarkan hasil pengamatan guru terhadap 27 peserta didik di siklus 2 semua dapat menjawab dengan baik dan benar, dan sudah $100 \%$ mencapai KKM. Penerapan metode modelling the way melalui media audio visual telah memberikan pengaruh yang sangat baik bagi peserta didik dalam meningkatkan hasil belajar, dan memotivasi peserta didik dalam proses belajar mengajar di kelas lebih bertambah semangat, hidup dan Percaya diri. Sehingga materi yang disampaikan guru dapat dengan mudah dipahami dan di mengerti oleh peserta didik. Tanggung jawab peserta didik terhadap tugas menjadi tinggi, serta membantu peserta didik untuk terlibat aktif di dalam kelas dan lebih kreatif dalam mengeluarkan ide-ide dalam kata-kata penulisan surat undangan
\end{abstract}

Kata kunci : modelling the way, audio visual, dan Bahasa Indonesia.

Abstract: Classroom Action Research carried out in two cycles for 27th grade students of Muhammadiyah 2 Elementary School in Depok consisting of male 24 and female 13. This study aims to increase motivation, interest, and results of learning Indonesian. In Prasiklus learning, the average results of students were 56.67, there were 10 students achieving the Maximum Completion Criteria or 37\%. The results of teacher observations of students who can answer teacher questions are only 7 students, or $26 \%$. Cycle 1 obtained an average value of 66.67 which reached a maximum criteria of completeness of 17 people or $63 \%$. Based on teacher observation data on students who can answer questions totaling 15 students or $56 \%$. Cycle 2 obtained an average value of 86.30 and all students had reached KKM. Based on the results of the teacher's observation of 27 students in cycle 2 all were able to answer well and correctly, and already $100 \%$ reached the Maximum Completion Criteria. The application of modeling the way method through audio visual media has provided a very good influence for students in improving learning outcomes, and motivating students in the teaching and learning process in the classroom to be more enthusiastic, alive and confident. So that the material delivered by the teacher can be easily understood and understood by students. The responsibility of students to the task becomes high, as well as helping students to be actively involved in the classroom and more creative in issuing ideas in invitation letter writing words 
Keywords: modeling the way, audio visual, and language

\section{PENDAHULUAN}

Pendidikan adalah usaha sadar dan terencana untuk mewujudkan suasana belajar dan proses pembelajaran agar peserta didik secara aktif mengembangkan potensi diri untuk memiliki kekuatan spiritual, keagamaan, pengendalian diri, kepribadian, kecerdasan, akhlak mulia, serta keterampilan yang diperlukan peserta didik, masyarakat, bangsa dan negara. Pemerintah merupakan salah satu penanggung jawab pendidikan, dengan melaksanakan pendidikan nasional (Sulfemi, 2013 : 17-26).

Belajar adalah perubahan tingkah laku peserta didik melalui latihan dan pengalaman yang dilakukan secara aktif. Hasilbelajar berupa pengetahuan, sikap atau keterampilan yang dibangun peserta didik berdasarkan apa yang telah dipahami dan dikuasai. Dalam pembelajaran tugas guru adalah menjadikan peserta didik belajar melalui penciptaan strategi dan lingkungan belajar yang menarik dan bermakna. Pembelajaran dapat dikatakan berhasil apabila peserta didik dapat menerima dan menguasai materi dengan baik (Sulfemi, dan Desmiati, Zulaicha, 2018 : 232-245).

Pembelajaran Bahaasa Indonesia bertujuan agar peserta didik dapat menggunakan Bahasa Indonesia sebagai alat berkomunikasi dengan baik dan benar sesuai etika dan kesopanan, dapat menghargai bahasa Indonesia dan mempunyai rasa bangga terhadap bahasa pemersatu bangsa tersebut. Dengan belajar bahasa Indonesia peserta didik diharapkan mampu membaca dan menulis untuk memperluas wawasan dan budi pekerti. Aspek kemampuan berbahasa meliputi beberapa hal, diantaranya aspek berbicara, mendengarkan, menulis dan membaca yang berhubungan dengan ragam bahasa.

Tujuan belajar bahasa Indonesia yaitu peserta didik dapat berbahasa Indonesia yang baik dan benar artinya sesuai dengan situasi dan kondisi yang ada sasuai kaidah bahasa, agar terampil dalam berbahasa Indonesia, keterampilan berbahasa (meliputi: menyimak, berbicara, membaca, dan menulis), dapat berkarya dan berimajinasi dengan baik.( Sulfemi, dan Minati., 2018 : 228-242)

Bahasa Indonesia memiliki peran yang sangat penting dalam peningkatan pendidikan baik bagi perorangan, masyarakat maupun bangsa dan Negara. Bahasa Indonesia merupakan mata pelajaran yang resmi di negara kita. Dalam pembelajaran ini peserta didik diharuskan mencapai Kriteria Ketuntasan Minimum (KKM). Artinya, peserta didik harus memahami mata pelajaran Bahasa Indonesia dan mendapatkan nilai 
sesuai atau melebihi KKM. Karena KKM dijadikan sebagai tolak ukur keberhasilan peserta didik dalam menerima pembelajaran di sekolah. Dengan demikian Pembelajaran bahasa Indonesia dalam kehidupan sehari-hari sangat memegang peranan penting terutama dalam menyimak. Menurut Tarigan dalam Nurjamal, dkk keterampilan berbahasa mencakup empat segi, yaitu menyimak (listening skill), berbicara (speaking skill), membaca (reading skill), dan menulis (writing skill.) (Nurjamal, D, dkk 2011:2).

Salah satu keterampilan berbahasa adalah keterampilan menulis. Menulis merupakan proses penuangan ide atau gagasan dalam bentuk paparan bahasa tulis berupa simbol-simbol bahasa. Menulis perlu dimulai dari mengenal huruf, menyusun kata, membentuk kalimat, paragraf sampai menulis karangan dengan baik. Oleh karena itu, guru harus mampu mengajarkan Bahasa Indonesia menggunakan metode dan media pembelajaran yang menarik untuk menciptakan interaksi antara peserta didik dengan peserta didik maupun antara peserta didik dengan guru, sehingga proses dan hasil pembelajaran dapat maksimal.

Pendidikan di sekolah dasar tidak hanya memberikan bekal kemampuan pengetahuan saja tetapi juga sikap dan keterampilan sebagai proses pengembangan diri dan sosial untuk melanjutkan pendidikan ke jenjang selanjutnya. Hal ini dikarenakan perkembangan dan perubahan di segala aspek kehidupan yang semakin pesat. (Sulfemi, 2017 : 342-357). Untuk itu pemerintah berupaya meningkatkan mutu pendidikan Nasional, antara lain melalui berbagai pelatihan kualitas guru, penyempurnaan kurikulum, perbaikan sarana dan prasarana pendidikan, serta pengadaan buku dan alat belajar secara gratis. Berbicara pembelajaran bahasa Indonesia di SD, sebaiknya melihat cara belajar peserta didik yang masih perlu banyak bimbingan dan arahan, agar peserta didik minat belajar dalam membaca lebih baik lagi. Guru harus mampu mengajarkan bahasa Indonesia dengan metode pembelajaran yang dapat membangkitkan semangat dalam pembelajaran. Karena keberhasilan implementasi strategi pembelajaran sangat tergantung pada cara guru menggunakan metode pembelajaran (Sulfemi, dan Setianingsih., $2018: 1-14)$

Berdasarkan hasil observasi peserta didik di SD Muhammadiyah 2 Depok tentang pembelajaran Bahasa Indonesia materi teks surat undangan dengan menggunakan metode ceramah dan menggunakan media gambar, ternyata belum efektif atau hasil belajarnya masih rendah, dari 27 peserta didik hasil prasiklus masih di bawah KKM 
(70), peserta yang tuntas 10 peserta didik (37\%), dan yang tidak tuntas 17 peserta didik (63\%). Pembelajaran Bahasa Indonesia tidak dapat diajarkan dengan metode ceramah saja, tetapi harus menggunakan metode yang variatif, agar peserta didik

Berbagai faktor penyebab rendahnya hasil belajar peserta didik dalam pelajaran Bahasa Indonesia, ada bebrapa faktor utama yang menyebabkan rendahnya hasil belajar Bahasa Indonesia adalah ketidak mampuan guru dalam menerapkan suatu metode yang tepat dalam memberikan pelajaran Bahasa Indonesia. Selain itu guru kurang mampu menumbuhkan minat belajar membaca dan menulis peserta didik, kurangnya minat membaca dan menulis merupakan faktor utama yang mempengaruhi hasil belajar peserta didik dalam pelajaran Bahasa Indonesia. Ditambah lagi kurangnya fasilitas sekolah sebagai daya dukung peserta didik dalam pembelajaran. Metode pengajaran merupakan cara yang digunakan guru dalam mengajarkan peserta didik agar terjadi interaksi dalam proses belajar. Guru harus mengunakan metode pembelajaran yang tepat agar proses belajar menjadi efektif dan membuat peserta didik lebih tertarik untuk mengikuti pembelajaran yang berujung pada peningkatan prestasi peserta didik. (Sulfemi dan Nurhasanah. 2018 : 151-158). Faktor lain ketidakberhasilan tersebut disebabkan karena tidak adanya media pembelajaran yang digunakan oleh guru dalam proses pembelajaran. Hal ini dikarenakan media memiliki andil untuk menjelaskan hal hal yang abstrak dan menunjukan hal-hal yang tersembunyi. Ketidakjelasan atau kerumitan materi pembelajaran dapat dibantu dengan menghadirkan media sebagai perantara. Bahkan dalam hal-hal tertentu media dapat mewakili kekurangan guru dalam mengkomunikasikan materi pelajaran. (Arsyad dan Sulfemi, 2018 : 41 - 46)

Oleh karena itu untuk memperbaiki hasil belajar peserta didik khususnya pada pelajaran Bahasa Indonesia Kelas 5 SD Muhammadiyah 2 Depok perlu adanya Penelitian Tindakan Kelas (PTK) di dalamnya. Berdasarkan latar belakang masalah di atas, peneliti tertarik untuk mengadakan penelitian dengan judul "Upaya Meningkatkan Hasil Belajar Bahasa Indonesia Materi Menulis Surat Undangan Kelas 5 SD Muhammadiyah 2 Depok Menggunakan Metode Modelling The Way Berbantu Media Audio Visual" 


\section{KAJIAN PUSTAKA}

\section{Hakekat Hasil Belajar Bahasa Indonesia}

Hasil belajar merupakan gabungan dari dua kata yaitu hasil dan belajar. Menurut Anitah (2017:2.5) belajar dapat dikatakan sebagai suatu proses, artinya dalam belajar akan terjadi proses melihat, membuat, mengamati, menyelesaikan masalah atau persoalan, menyimak, dan latihan. Dalam proses belajar guru harus dapat membimbing dan memfasilitasi peserta didik agar dapat melakukan proses pembelajaran tersebut. Dalam belajar semua aspek di dalam diri peserta didik sebagai individu seperti intelektual, sosial-emosional, fisik semua itu harus terlibat secara utuh, sehingga perkembangan potensi, bakat, minat peserta didik secara maksimal.

Menurut Sulfemi, (2018 : 166-178) keberhasilan belajar sangat dipengaruhi oleh beberapa faktor. Faktor-faktor tersebut dikelompokkan menjadi dua kelompok yaitu faktor dalam diri peserta didik sendiri (intern) dan faktor dari luar diri peserta didik (ekstern).

Pembelajaran bahasa Indonesia diarahkan dalam rangka untuk meningkatkan kemampuan peserta didik untuk berkomunikasi dalam bahasa Indonesia dengan baik dan benar secara lisan maupun tulis dan menumbuhkan apresiasi terhadap hasil karya kesastraan manusia Indonesia.

Menurut Mulyati (2015:13) "Hakikat bahasa dilihat dari aspek bunyi/isyarat, simbol (huruf atau gambar), dan makna. Dari ketiga aspek ini dapat didefinisikan bahwa "bahasa" adalah suatu bunyi ujaran/isyarat yang dapat disimbolkan melalui huruf atau gambar yang berbeda-beda, masing-masing bunyi atau isyarat dan simbol atau gambar tersebut memiliki makna yang berbeda-beda pula".

Berdasarkan uraian di atas dapat disimpulkan bahwa pembelajaran bahasa Indonesia di SD adalah salah satu pembelajaran yang mempersiapkan peserta didik agar mampu berkomunikasi dengan baik dan benar, terampil dalam menyimak, berbicara, membaca, dan menulis bahasa Indonesia.

Sedangkan hakikat pembelajaran bahasa Indonesia adalah meningkatkan cara berkomunikasi dengan tata bahasa yang baik dan benar agar dapat dipahami dan diterima oleh pihak yang diajak komunikasi, baik dalam lisan maupun tulisan sehingga hasil belajar peserta didik menjadi efektif dan mencapai KKM. 


\section{Hakikat Metode Modelling The Way}

Menurut Hisyam Zaini, dkk (2008) Metode modeling the way (membuat contoh praktek) adalah metode pembelajaran yang memberi kesempatan kepada peserta didik untuk mempraktekkan keterampilan spesifik yang dipelajari di kelas melalui demonstrasi. Peserta didik diberi waktu untuk menciptakan skenario sendiri dan menentukan bagaimana mereka mengilustrasikan keterampilan dan teknik yang baru saja dijelaskan.

Strategi modeling the way sebagai salah satu strategi pembelajaran dalam pelaksanaannya mempunyai beberapa kelebihan yaitu: 1) Dapat membuat pembelajaran menjadi lebih jelas dan konkrit, sehingga menghindari verbalisme (pemahaman secara kata-kata atau kalimat). 2) Peserta didik lebih mudah memahami apa yang dipelajari. 3) Proses pembelajaran lebih menarik dan peserta didik dirangsang untuk aktif mengamati, menyesuaikan antara teori dan kenyataan dan mencoba melakukannya sendiri. (Muhaimin, dan Abdul Mujib, $2000: 153-154)$

Perencanaan dan persiapan metode strategi modeling the way harus diikuti dengan kesiapan guru, dalam hal ini guru harus merencanakan demonstrasi yang efektif. Adapun langkah-langkah perencanaan tersebut yaitu, sebagai berikut: 1) Merumuskan tujuan yang jelas dari sudut percakapan dan kegiatan yang diharapkan dapat dicapai/dilaksanakan oleh peserta didik itu sendiri bila peragaan itu berakhir, 2) Menetapkan garis besar langkah-langkah peragaan yang akan dilaksanakan dan sebaiknya sebelum demonstrasi dilakukan oleh guru sudah dicoba terlebih dahulu supaya tidak gagal pada waktunya, dan 3)Menetapkan rencana untuk menilai kemajuan peserta didik. Seringkali terlebih diadakan diskusi dan peserta didik mencoba lagi peragaan dan eksperimen agar memperoleh kecekatan yang lebih baik (Zuhairini, dkk, 2001 : 297).

\section{Media Pembelajaran Audio Visual}

Menurut Zahroh.(2015:207) media pembelajaran diartikan sebagai segala sesuatu yang dapat digunakan untuk menyalurkan pesan (message), merangsang pikiran, perasaan, perhatian dan kemauan siswa sehingga dapat mendorong proses belajar. Bentuk-bentuk media pembelajaran digunakan untuk meningkatkan pengalaman belajar agar menjadi lebih konkrit. 
Suprijono, (2005:171) menyampaikan media audio visual adalah media yang mempunyai unsur suara dan unsur gambar. Jenis media ini mempunyai kemampuan yang lebih baik, karena meliputi kedua jenis media auditif (mendengar) dan visual (melihat). Media Audio visual merupakan sebuah alat bantu audio visual yang berarti bahan atau alat yang dipergunakan dalam situasi belajar untuk membantu tulisan dan kata yang diucapkan dalam menularkan pengetahuan, sikap, dan ide. Media audio visual merupakan media perantara atau penggunaan materi dan penyerapannya melalui pandangan dan pendengaran sehingga membangun kondisi yang dapat membuat siswa mampu memperoleh pengetahuan, keterampilan, atau sikap.

Wina Sanjaya (2011:211) Media Audio Visual yaitu jenis media yang selain mengandung unsur suara juga mengandung unsur gambar yang dapat dilihat, seperti rekaman video, berbagai ukuran film, slide suara, dan lain sebagainya. Kemampuan media ini dianggap lebih baik dan lebih menarik, sebab mengandung kedua unsur jenis media yang pertama dan kedua. Menurut Sadiman (2010:74) Media audio visual yaitu media yang menampilkan gerak dan suara sebagai pesan yang disajikan berupa fakta maupun fiktif bias bersifat edukatif maupun intruksional. Sedangkan menurut Daryanto (2015:87) Media audio visual adalah segala sesuatu yang memungkinkan sinyal audio dapat dikombinasikan dengan gambar bergerak secara sekuensial.

Berdasarkan beberapa pengertian diatas dapat disimpulkan bahwa media audio visual adalah media yang digunakan sebagai alat bantu dalam proses pembelajaran yang menampilkan gerak dan suara agar peserta didik lebih tertarik dalam menerima materi dan dapat meningkatkan kulitas hasil belajar yang lebih baik dalam pembelajaran Bahasa Indonesia materi menulis surat undangan.

\section{METODE PENELITIAN}

Dalam penelitian tindakan kelas ini yang menjadi subjek penelitian adalah peserta didik kelas V SD Muhammadiyah 2 Depok sebanyak 27 peserta didik terdiri dari Lakilaki 24 dan perempuan 13. Peneliti melaksanakan perbaikan pembelajaran kepada peserta didik di kelas karena hasil evaluasi pembelajaran yang selalu rendah, sehingga peneliti termotivasi untuk melaksanakan penelitian ini dengan harapan dapat menemukan dan memperbaiki masalah-masalah pembelajaran 
Model PTK yang digunakan adalah model Elliot yang mensyaratkan bahwa kegiatan penelitian tindakan dilakukan melalui tahapan-tahapan penelitian yakni perencanaan umum, implementasi, monitoring implementasi dan efek, penjelasan kegagalan, dan rancangan ulang. Secara garis besar terdapat empat tahapan yang lazim dilalui ketika melakukan penelitian tindakan. Tahapan-tahapan tersebut menurut Mills (2011) dalam Miaz, ( 2015 : 2) adalah sebagai berikut: 1) Menyusun rancangan tindakan (planning), 2) Pelaksanaan tindakan (acting), 3) Pengamatan (observing), dan 4) Refleksi (reflecting).

Untuk analisis data penelitian menggunakan analisis deskriptif kuantitatif dan deskriptif kualitatif. 1. Analisis Tes Analisis yang digunakan untuk mengetahui hasil belajar pada siswa kelas $\mathrm{V}$ adalah statistik deskriptif, yaitu dengan mencari rerata dari skor terendah sampai skor tertinggi.

Data yang dikumpulkan pada setiap kegiatan penelitian dari pelaksanaan siklus penelitian dianalsis secara deskriptif dengan menggunakan teknik persentase untuk melihat kecenderungan yang terjadi dalam kegiatan pembelajaran mata pelajaran IPS.Untuk menilai ulangan atau tes formatif dilakukan penjumlahan nilai yang diperoleh peserta didik, yang selanjutnya dibagi dengan jumlah peserta didik yang ada di kelas tersebut sehingga diperoleh rata-rata tes formatif dapat dirumuskan $\bar{X}=\frac{\sum X}{\sum N}$, Rentang Data dengan rumus $\mathrm{R}=\mathrm{X}_{\mathrm{t}}-\mathrm{X}_{\mathrm{r}}$, Banyaknya Kelas $(\mathrm{BK})$ dengan rumus $\mathrm{K}=1+$ 3,3 $\log n$, Panjang Interval $(\mathrm{P})$ dengan rumus $\mathrm{P}=\frac{\mathrm{R}}{\mathrm{BK}}$, Presentase frekuensi dengan rumus $\mathrm{P}=\frac{f}{N} \times 100 \%$.

Kategori ketuntasan belajar berdasarkan petunjuk pelaksanaan belajar mengajar kurikulum 1994 (Depdikbud, 1994), yaitu seorang peserta didik telah tuntas belajar bila telah mencapai skor $65 \%$ atau nilai 75 , dan kelas disebut tuntas belajar bila di kelas tersebut terdapat $85 \%$ yang telah mencapai daya serap lebih dari sama dengan $65 \%$. Untuk menghitung persentase ketuntasan belajar digunakan rumus sebagai berikut: $\mathrm{P}=$ $\frac{\text { Spesertadidikyangtuntasbelajar }}{\text { Npesertadidikkeseluruhan }} \times 100 \%$

Hasil data yang dikumpulkan pada setiap ksgiatan penelitian dari pelaksanaan siklus penelitian dianalisis secara deskriptif dengan menggunakan teknik persentase untuk dapat melihat kecenderungan yang terjadi Wardani, (2014 : 1.4) dalam kegiatan pembelajaran mata pelajaran Bahasa Indonesia. 


\section{HASIL DAN PEMBAHASAN}

Dalam pembelajaran Prasiklus materi "Menulis Tek Surat Undangan" dengan KKM 70, dari jumlah 27 peserta didik diperoleh hasil rata-rata peserta didik 56,67 dengan perincin data sebagai berikut, jumlah nilai keseluruhan 1530, nilai tertinggi 80 , dan nilai terendah 30 . Terdapat 10 orang peserta didik mencapai KKM atau $37 \%$ sedangkan yang belum mencapai KKM berjumlah 17 peserta didik atau $63 \%$. Hasil pengamatan guru terhadap peserta didik yang dapat menjawab pertanyaan guru hanya 7 peserta didik, atau sebesar $26 \%$ sedangkan yang tidak dapat pertanyaan guru terdapat 20 peserta didik atau sebesar 74\%. Dalam kegiatan pembelajaran pada Prasiklus ini sangat rendah dan tidak memuaskan.

Berdasarkan data diatas Prasiklus dapat dibuat Distribusi Frekuensi (F) sebagai berikut

\section{Tabel 1}

\section{Distribusi Frekuensi (F)Hasil Prasiklus}

\begin{tabular}{|c|c|c|c|c|}
\hline No. & Skor (S) & Frekuensi (F) & \% & S x F \\
\hline 1 & 100 & 0 & 0 & 0 \\
\hline 2 & 90 & 0 & 0 & 0 \\
\hline 3 & 80 & 2 & 7,41 & 160 \\
\hline 4 & 70 & 8 & 29,63 & 560 \\
\hline 5 & 60 & 3 & 11,11 & 180 \\
\hline 6 & 50 & 9 & 33,33 & 450 \\
\hline 7 & 40 & 3 & 11,11 & 120 \\
\hline 8 & 30 & 2 & 7,41 & 60 \\
\hline 9 & 20 & 0 & 0 & 0 \\
\hline 10 & 10 & 0 & 0 & 0 \\
\hline \multicolumn{2}{|c|}{ Jumlah } & $\mathbf{2 7}$ & $\mathbf{1 0 0 \%}$ & $\mathbf{1 5 3 0}$ \\
\hline
\end{tabular}

Berdasarkan data hasil perhintungan interval kelas yang disajikan dalam tabel interval hasil evaluasi nilai Bahasa Indonesia Prasiklus dapat dibuat grafik frekuensi hasil belajar Bahasa Indonesia pada proses pembelajaran. Berikut frekuensi hasil Prasiklus hasil belajar Bahasa Indonesia. 


\section{Grafik 1}

Frekuensi Hasil Belajar Bahasa Indonesia Prasiklus

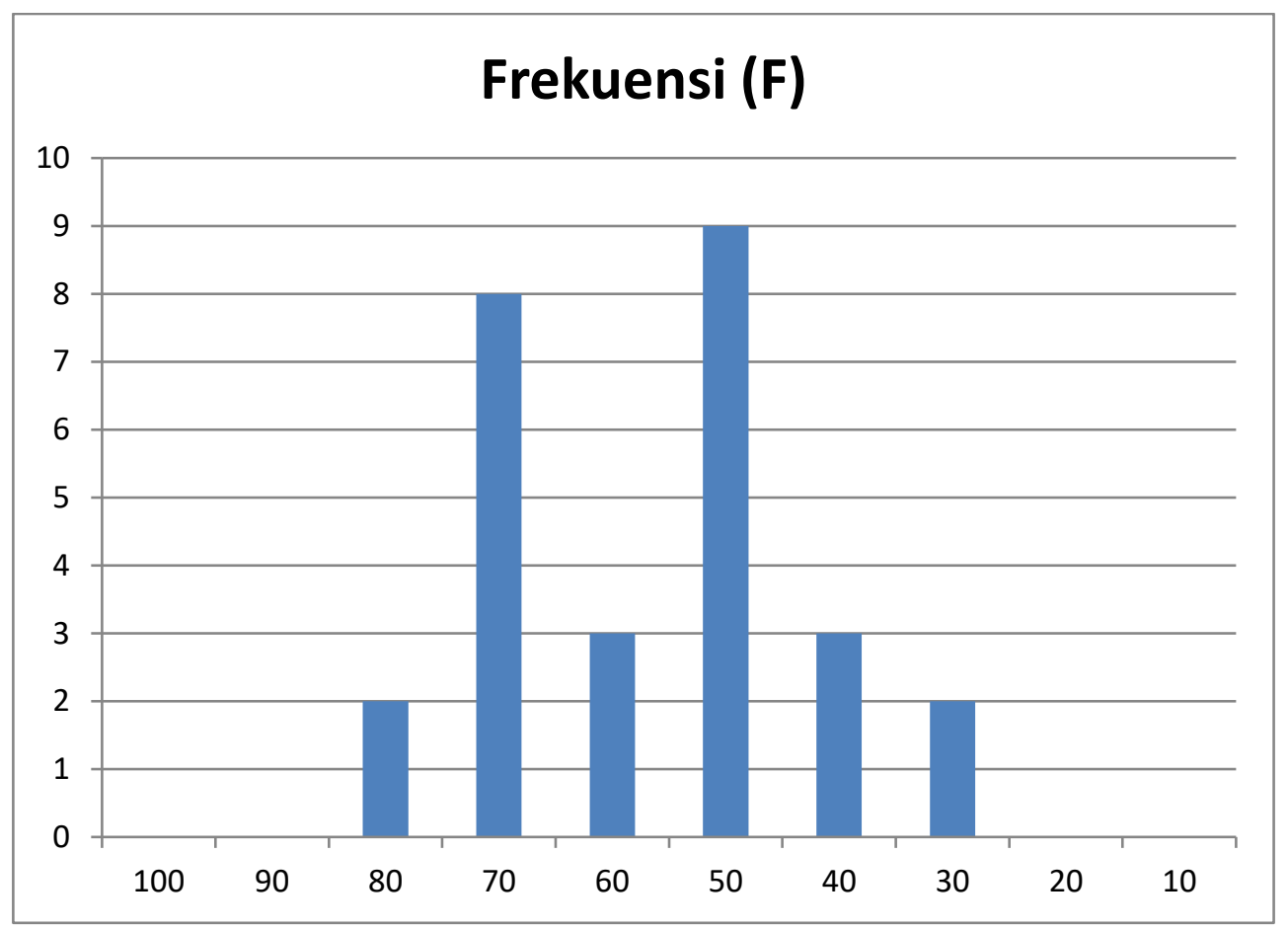

Dari deskripsi di atas dapat disimpulkan bahwa hasil belajar peserta didik mendapatkan skor di bawah KKM (70). Berdasarkan nilai rata-rata dapat di simpulkan bahwa peserta didik belum memahami materi.

Dalam pelaksanaan pembelajaran Siklus 1 diperoleh rata-rata nilai 66,67 dengan perincian sebagai berikut: jumlah nilai keseluruhan 1800, nilai tertinggi 90, dan nilai terendah 40, dan peserta didik yang mencapai KKM (70) berjumlah 17 (63\%) peserta didik, sedangkan yang belum mencapai KKM (70) 10 (37\%) peserta didik. Berdasarkan data pengamatan guru terhadap peserta didik yang dapat menjawab pertanyaan berjumlah 15 peserta didik atau 56\% sedangkan yang tidak dapat menjawab pertanyaan guru terdapat 12 peserta didik atau 44\%. Dengan demikian pada siklus 1 peneliti belum puas dengan hasil pembelajaran yang didapatkan peserta didik, sehingga akan di lanjutkan pada siklus 2 .

Berdasarkan data diatas dapat dibuat Distribusi Frekuensi (F) sebagai berikut 
Tabel 2

Distribusi Hasil Siklus 1

\begin{tabular}{|c|c|c|c|c|}
\hline No. & Skor $(\mathrm{S})$ & Frekuensi (F) & $\%$ & S x F \\
\hline 1 & 100 & 0 & 0 & 0 \\
\hline 2 & 90 & 1 & 3,71 & 90 \\
\hline 3 & 80 & 7 & 25,93 & 560 \\
\hline 4 & 70 & 9 & 33,33 & 630 \\
\hline 5 & 60 & 4 & 14,81 & 240 \\
\hline 6 & 50 & 4 & 14,81 & 240 \\
\hline 7 & 40 & 2 & 7,41 & 80 \\
\hline 8 & 30 & 0 & 0 & 0 \\
\hline 9 & 20 & 0 & 0 & 0 \\
\hline 10 & 10 & 0 & 0 & 0 \\
\hline \multicolumn{2}{|c|}{ Jumlah } & 27 & $100 \%$ & 1840 \\
\hline
\end{tabular}

Berdasarkan data hasil perhintungan interval kelas yang disajikan dalam tabel interval hasil evaluasi nilai Bahasa Indonesia siklus 1dapat dibuat grafik frekuensi hasil belajar Bahasa Indonesia pada proses pembelajaran. Berikut frekuensi hasil siklus 1 hasil belajar Bahasa Indonesia.

\section{Grafik 2}

Frekuensi Hasil Belajar Bahasa Indonesia Siklus 1

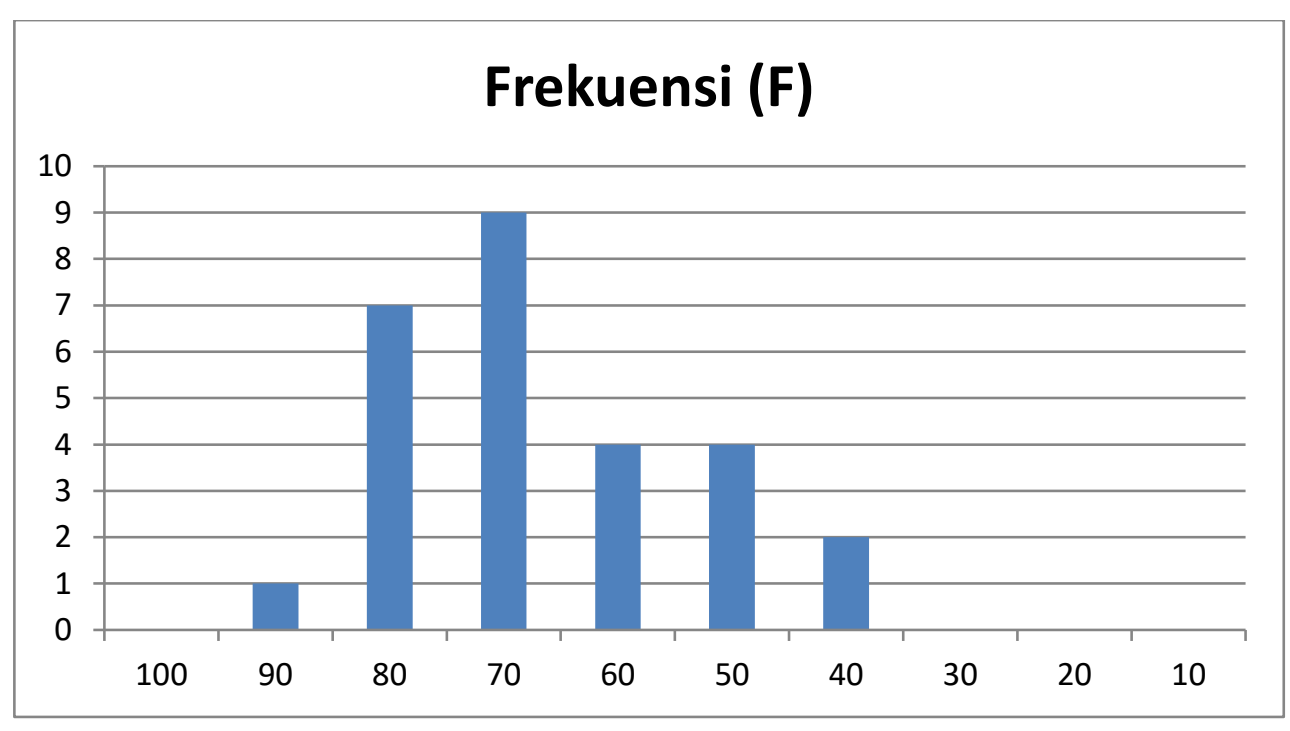

Berdasarkan deskripsi diatas dapat disimpulkan bahwa nilai rata-rata hasil belajar peserta didik kelas 5 SD Muhammadiyah 2 Depok dalam pembelajaran Bahasa Indonesia materi menulis surat undangan belum mendapatkan hasil yang maksimal dan masih di bawah KKM (70). 
Dalam pelaksanaan pembelajaran siklus 2 di SD Muhammadiyah 2 pelajaran Bahasa Indonesia materi "Menulis Teks Surat Undangan" dengan KKM (70). Peneliti memperbaiki pembelajaran menulis surat undangan dengan metode yang lebih bervariasi yaitu dengan metode modelling the way melalui media audio visual menggunakan laptop dan LCD. Dari hasil evaluasi siklus 2 jumlah 27 peserta didik diperoleh rata-rata nilai 86,30 dengan perincian sebagai berikut: jumlah nilai keseluruhan 2330, nilai tertinggi 100, dan nilai terendah 70, dan semua peserta didik sudah mencapai KKM (70), sehingga peneliti sudah tidak perlu untuk melanjutkan ke siklus berikutnya. Berdasarkan hasil pengamatan guru terhadap 27 peserta didik di siklus 2 semua dapat menjawab dengan baik dan benar, dan sudah 100\% mencapai KKM (70).

Dalam kegiatan pembelajaran pada Siklus 2 ini peserta didik sangat percaya diri dan bersemangat dalam mengikuti pelajaran Bahasa Indonesia. Penyebabnya karena media yang digunakan guru sudah tepat dan sesuai dengan materi yang di ajarkan selama proses belajar mengajar berlangsung, sehingga tercipta suasana pembelajaran yang menarik, menyenangkan dan menghilangkan rasa bosan dan jenuh, sehingga dapat pula meningkatkan hasil belajar peserta didik dengan baik.

Berdasarkan data diatas dapat dibuat Distribusi Frekuensi (F) sebagai berikut

Tabel 3

Distribusi Hasil Siklus 2

\begin{tabular}{|c|c|c|c|c|}
\hline No. & Skor $(\mathrm{S})$ & Frekuensi $(\mathrm{F})$ & $\%$ & $\mathrm{~S} \times \mathrm{F}$ \\
\hline 1 & 100 & 6 & 22,22 & 600 \\
\hline 2 & 90 & 9 & 33,33 & 810 \\
\hline 3 & 80 & 8 & 29,63 & 640 \\
\hline 4 & 70 & 4 & 14,81 & 280 \\
\hline 5 & 60 & 0 & 0 & 0 \\
\hline 6 & 50 & 0 & 0 & 0 \\
\hline 7 & 40 & 0 & 0 & 0 \\
\hline 8 & 30 & 0 & 0 & 0 \\
\hline 9 & 20 & 0 & 0 & 0 \\
\hline 10 & 10 & 0 & 0 & 0 \\
\hline & Jumlah & 27 & $100 \%$ & 2330 \\
\hline
\end{tabular}

Berdasarkan data hasil perhintungan interval kelas yang disajikan dalam tabel interval hasil evaluasi nilai Bahasa Indonesia siklus 2 dapat dibuat grafik frekuensi hasil belajar Bahasa Indonesia pada proses pembelajaran. Berikut frekuensi hasil siklus 1 hasil belajar Bahasa Indonesia. 


\section{Grafik 3}

Frekuensi Hasil Belajar Bahasa Indonesia Siklus 2

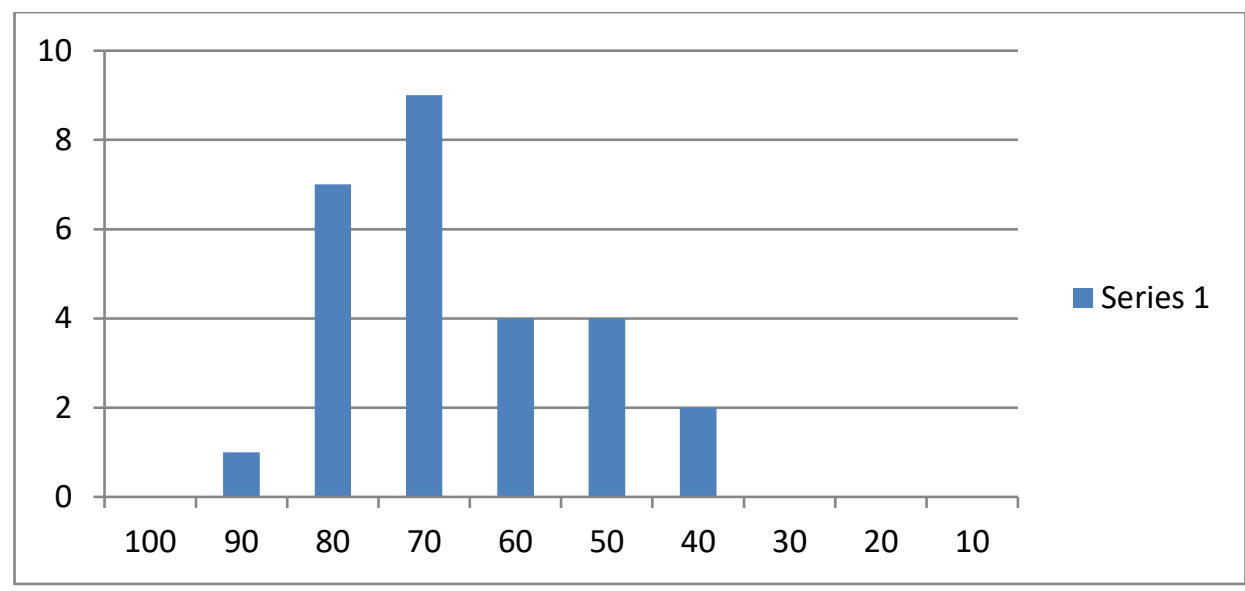

Sedangkan data pengamatan guru terhadap peserta didik, alhamdulillah semua peserta didik sudah dapat menjawab pertanyaan yang diajukan guru. Hasil pengamatan yaitu semua dapat menjawab dengan baik dan benar, dan sudah $100 \%$ mencapai KKM (70).

Dengan demikian, hasil pembelajaran Siklus 2 di atas sudah sepenuhnya peserta didik mencapai KKM (70). Berdasarkandeskripsi di atas dapat disimpulkan bahwa hasil peserta didik mendapatkan skor sesuai KKM. Berdasarkan nilai rata-rata dapat di simpulkan bahwa peserta didik sudah $100 \%$ mencapai KKM.

Berdasarkan uraian di atas berikut ini peneliti sajikan rekapitulasi nilai rata-rata tiap siklus. Perbandingan perolehan nilai dan ketuntasan belajar pada prasiklus, siklus 1 , dan siklus 2, terus mengalami peningkatan. Perolehan nilai rata-rata sebesar 56,67; 66,67; dan 86,30. Berikut rangkuman Hasil Belajar Peserta Didik dan Hasil pengamatan Belajar Peserta Didik setiap siklus yang disajikan dalam tebel dan grafik berikut ini

\section{Tabel 4}

Rankumana Persentase Keberhasilan Hasil Belajar Peserta Didik

\begin{tabular}{|c|l|c|c|c|c|c|c|}
\hline \multirow{2}{*}{ No } & \multirow{2}{*}{ Kriteria } & \multicolumn{2}{|c|}{ Prasiklus } & \multicolumn{2}{c|}{ Siklus 1 } & \multicolumn{2}{c|}{ Siklus 2 } \\
\cline { 3 - 8 } & & Jumlah & $\%$ & Jumlah & $\%$ & Jumlah & $\%$ \\
\hline 1 & Tuntas & 10 & 37 & 17 & 63 & 27 & 100 \\
\hline 2 & Belum Tuntas & 17 & 63 & 10 & 37 & 0 & 0 \\
\hline 3 & Rerata kelas & \multicolumn{2}{|c|}{56,67} & \multicolumn{2}{|c|}{66,67} & \multicolumn{2}{c|}{86,30} \\
\hline
\end{tabular}

Berdasarkan tabel 4 rangkuman Hasil Belajar Peserta Didik dapat di buat grafik berikut grafik ini 


\section{Grafik 4}

\section{Ketuntasan Belajar Peserta Didik Setiap Siklus}

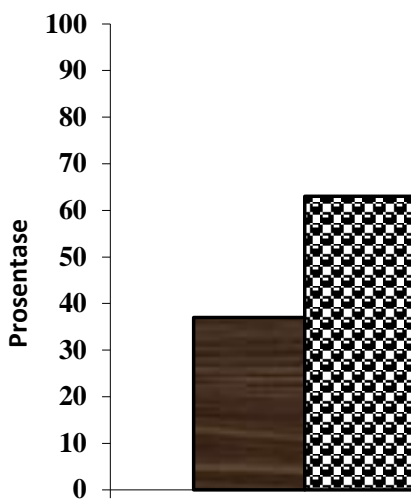

Pra Siklus

\section{$\square$ tuntas $\mathrm{g}$ Tidak tuntas}

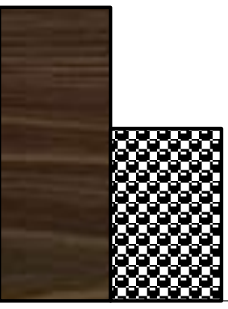

Siklus I

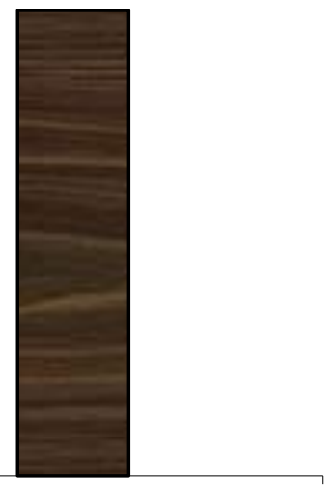

Siklus II

Grafik 5

Prosentase Keberhasilan Peserta Didik

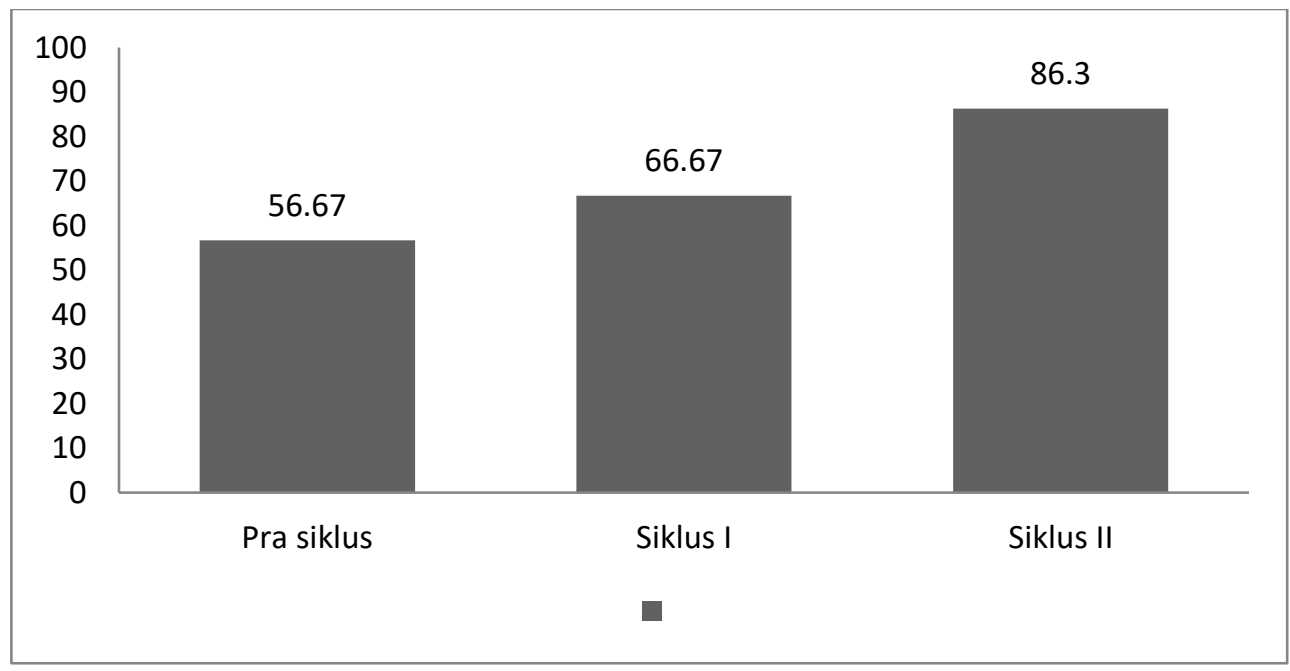

Tabel 6

Rangkum Data Pengamatan Guru Terhadap Peserta Didik yang Dapat Menjawab dan Tidak Menjawab Pada Setiap Siklus

\begin{tabular}{|c|l|c|c|c|c|c|c|}
\hline \multirow{2}{*}{ No. } & \multirow{2}{*}{ Kriteria } & \multicolumn{2}{|c|}{ Prasiklus } & \multicolumn{2}{c|}{ Siklus 1 } & \multicolumn{2}{c|}{ Siklus 2 } \\
\cline { 3 - 8 } & & Jumlah & $\%$ & Jumlah & $\%$ & Jumlah & $\%$ \\
\hline 1 & Dapat Menjawab & 7 & 26 & 15 & 56 & 27 & 100 \\
\hline 2 & $\begin{array}{l}\text { Tidak Dapat } \\
\text { Menjawab }\end{array}$ & 20 & 74 & 12 & 44 & 0 & 0 \\
\hline 3 & Jumlah & 27 & 100 & 27 & 100 & 27 & 100 \\
\hline
\end{tabular}

Berdasarkan tabel 6 rangkum data pengamatan guru terhadap peserta didik yang dapat menjawab dan tidak menjawab pada setiap siklus dapat di buat grafik berikut ini 


\section{Grafik 6 \\ Pengamatan Guru Terhadap Peserta Didik \\ yang Dapat Menjawab dan Tidak Dapat Menjawab}

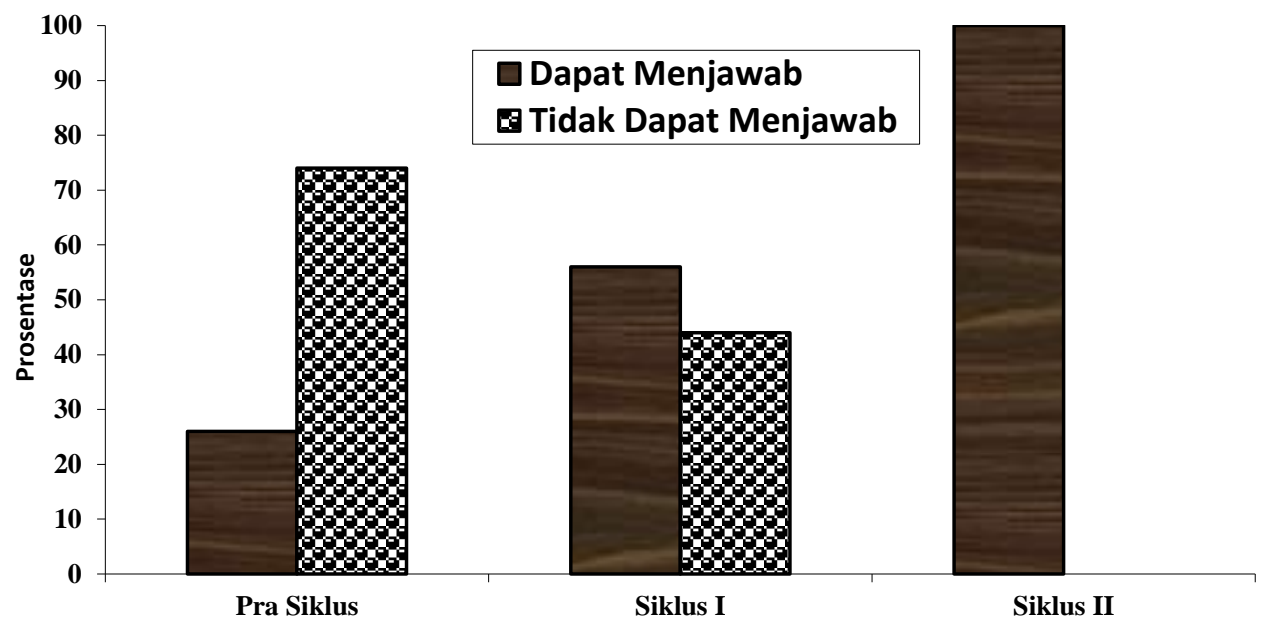

Dalam pembelajaran Prasiklus setelah guru melaksanakan evaluasi pembelajaran, ternyata rendahnya hasil belajar peserta didik disebabkan oleh metode yang kurang tepat dalam pembelajaran, guru hanya menggunakan metode ceramah saja, sehingga peserta didik hanya mendengarkan dan tidak dilibatkan untuk berperan aktif selama proses pembelajaran berlangsung, sehingga menyebabkan peserta didik merasa bosan dan jenuh, ngantuk dan tidak termotivasi untuk mengikuti proses pembelajaran

Hasil ini juga sesui dengan penelitian Habiba (2017 : 85-91) dan Permatasari, (2017 : 96-104), dimana rendahnya minat, motivasi, rendahnya hasil belajar dan peserta didik kurang aktif dalam proses pembelajaran, hal ini terbukti dengan sedikit sekali peserta didik yang bertanya, sedikit sekali peserta didik yang dapat menjawab pertanyaan yang diajukan oleh guru, tidak adanya diskusi, dan tidak ada kerjasama Mata Pelajaran Bahasa Indonesia karena hal berikut ini : 1). model pembelajaran yang digunakan kurang menarik dimana guru menjadi teacher center sehingga banyak peserta didik yang kesulitan memahami materi, 2) penggunaa metode pembalajaran yang tidak menarik, bervariasi dan efektif yang sesuai secara maksimal sehingga peserta didik mengalami kesulitan, 3) tidak adanya penggunaan media pembelajaran yang membuat peserta didik tidak tertarik untuk belajar, 4) Guru jarang mengadakan dan reward kepada umpan balik secara langsung selama pembelajaran, sehingga peserta didik tidak aktif, 5) Guru kurang memberikan kesempatan kepada peserta didik untuk 
bertanya dan melibatkan peserta didik dalam materi ini, 6) Guru kurang memberikan motivasi pada saat pembelajaran berlangsung sehingga peserta didik tidak tertarik pada pelajaran Bahasa Indonesia. Untuk mengatasi permasalahan tersebut maka peneliti perlu menambahkan metode pembelajaran yang lebih tepat dengan melibatkan dan menarik minat peserta didik.

Setelah pembelejaran Prasiklus yang jauh dari KKM maka dilakukan pembelajaran ke Siklus 1. Dalam pelaksanaan pembelajaran Siklus 1 yang dilaksanakan pada hari Kamis tanggal 2 Agustus 2018 jam 8.30 s/d 9.40 pelajaran Bahasa Indonesia materi “Menulis Teks Surat Undangan” dengan menggunakan metode diskusi dan media papan tulis. Pada kegiatan siklus 1 dari jumlah 27 peserta didik diperoleh ratarata nilai 66,29 dengan perincian sebagai berikut: jumlah nilai keseluruhan 1790, nilai tertinggi 90, dan nilai terendah 40, dan peserta didik yang mencapai KKM (70) berjumlah 17 (63\%) peserta didik, sedangkan yang belum mencapai KKM (70) 10 (37\%) peserta didik. Berdasarkan pengamatan guru terhadap peserta didik yang dapat menjawab pertanyaan berjumlah 15 peserta didik atau $56 \%$ sedangkan yang tidak dapat menjawab pertanyaan guru terdapat 12 peserta didik atau 44\%. Dengan demikian pada siklus 1 peneliti belum puas dengan hasil pembelajaran yang didapatkan peserta didik, sehingga akan di lanjutkan pada siklus 2

Dalam pelaksanaan pembelajaran siklus 2 di SD Muhammadiyah 2 Depok, Jl. K.H.Ahmad Dahlan No.1 Rangkapan Jaya Baru Pancoran Mas Depok yang dilaksanakan pada hari Kamis tanggal 9 Agustus 2018 jam 8.30 s/d 9.40 pelajaran Bahasa Indonesia materi "Menulis Teks Surat Undangan” dengan KKM (70). Peneliti memperbaiki pembelajaran menulis surat undangan dengan metode yang lebih bervariasi yaitu dengan metode modelling the way melalui media audio visual menggunakan laptop dan LCD. Dari hasil evaluasi siklus 2 jumlah 27 peserta didik diperoleh rata-rata nilai 86,30 dengan perincian sebagai berikut: jumlah nilai keseluruhan 2330, nilai tertinggi 100 , dan nilai terendah 70 , dan semua peserta didik sudah mencapai KKM (70), sehingga peneliti sudah tidak perlu untuk melanjutkan ke siklus berikutnya. Berdasarkan hasil pengamatan guru terhadap 27 peserta didik di siklus 2 semua dapat menjawab dengan baik dan benar, dan sudah $100 \%$ mencapai KKM (70). 
Penggunaan Metode Modelling The Way menjadikan mendidik peserta didik mampu menyelesaikan sendiri problema sosial yang ia jumpai, peserta didik berbahasa yang baik dan dapat menyalurkan pikiran serta perasaannya dengan jelas dan tepat, memperkaya pengetahuan dan pengalaman peserta didik, memupuk perkembangan kreativitas anak, dan mau menerima dan menghargai pendapat orang lain.

Metode Modelling The Way menjadikan seperti yang disampaikan Solchan, dkk. (2011: 7.5) bahwa sesuai dengan tujuan Mata Pelajaran Bahasa agar peserta didik memiliki berbagai kemampuan sebagai berikut: 1) Berkomunikasi secara efektif dan efesien sesuai etika yang berlaku, baik secara lisan maupun tulis, 2) Menghargai dan bangga menggunakan bahasa Indonesia sebagai persatuan dan bahasa negara. 3) Memahami bahasa Indonesia dan menggunakannya dengan tepat dan kreatif untuk berbagai tujuan, 4) Menggunakan bahasa Indonesia untuk meningkatkan kemampuan intelektual, serta kematangan emosional dan social, 5) Menikmati dan memanfaatkan karya sastra untuk memperluas wawasan, memperhalus budi pengerti, serta meningkatkan pengetahuan dan kemampuan berbahasa, 6) Menghargai dan membanggakan sastra Indonesia sebagai khazanah budaya dan intelektual manusia Indonesia.

Demikian pula pembelajaran bahasa Indonesia peserta didik tingkat SD memiliki kemampuan dalam berkomunikasi dengan bahasa yang baik dan benar. Guru dapat mengetahui penguasaan pembelajaran bahasa Indonesia peserta didik dari standar kompetensi yang meliputi dari cara membaca, menulis, berbicara, dan mendengarkan. Untuk meningkatkan kualitas bahasa Indonesia peserta didik perlu diperhatikan sejak dini, mulai dari sekolah dasar yang merupakan dasar pembentukan kompetensi keterampilan berbahasa Indonesia untuk dipersiapkan ke jenjang yang lebih tinggi lagi.

\section{SIMPULAN DAN SARAN}

Berdasarkan hasil Penelitian Tindakan Kelas (PTK) melalui aktivitas perbaikan pembelajaran yang telah dilaksanakan mulai dari prasiklus, siklus I sampai dengan siklus II pada peserta didik kelas V SD Muhammadiyah 2 Depok sebanyak 27 peserta didik terdiri dari Laki-laki 24 dan perempuan 13 mata pelajaran bahasa Indonesia materi menulis surat undangan ditari kesimpulan sebagai berikut: 1) Dalam pembelajaran Prasiklus diperoleh hasil rata-rata peserta didik 56,67, terdapat 10 orang peserta didik 
mencapai KKM atau 37\%. Hasil pengamatan guru terhadap peserta didik yang dapat menjawab pertanyaan guru hanya 7 peserta didik, atau sebesar 26\%. Siklus 1 diperoleh rata-rata nilai 66,67 yang mencapai KKM 17 (63). Berdasarkan data pengamatan guru terhadap peserta didik yang dapat menjawab pertanyaan berjumlah 15 peserta didik atau $56 \%$. Siklus 2 diperoleh rata-rata nilai 86,30 dan semua peserta didik sudah mencapai KKM (70), Berdasarkan hasil pengamatan guru terhadap 27 peserta didik di siklus 2 semua dapat menjawab dengan baik dan benar, dan sudah $100 \%$ mencapai KKM (70). 2) Penggunaan Metode modelling the way (pemberian contoh) dapat meningkatkan hasil belajar peserta didik sampai $66,27 \%$ pada siklus 1, dan guru dapat menemukan kesulitan-kesulitan dalam proses pembelajaran yang dialami peserta didik dalam menulis surat undangan. 3) Penerapan metode modelling the way melalui media audio visual telah memberikan pengaruh yang sangat baik bagi peserta didik dalam meningkatkan hasil belajar, dan memotivasi peserta didik dalam proses belajar mengajar di kelas lebih bertambah semangat, hidup dan percaya diri. Sehingga materi yang disampaikan guru dapat dengan mudah dipahami dan di mengerti oleh peserta didik. Dan tanggung jawab peserta didik terhadap tugas menjadi tinggi, serta membantu peserta didik untuk terlibat aktif di dalam kelas dan lebih kreatif dalam mengeluarkan ide-ide dalam kata-kata penulisan surat undangan

Berdasarkan pada kesimpulan diatas ada beberapa hal yang sebaiknya dilakukan guru dalam upaya meningkatkan hasil belajar peserta didik dalam pembelajaran dan proses kegiatan belajar mengajar. 1) Guru memberikan motivasi yang kuat kepada peserta didik sebelum melakukan pembelajaran, 2) Guru diharapkan mampu menerapkan metode dan media yang sesuai dengan pembelajaran, agar pembelajaran lebih menyenangkan dan menarik bagi peserta didik. 3) Menjadikan kelas menjadi hidup dalam kegiatan belajar, agar peserta didik lebih aktif di dalam proses pembelajaran, dan 4) Kepala sekolah hendaknya mampu menjadi motivator guru untuk menerapkan berbagai model dan media pembelajaran sehingga guru secara terusmenerus melakukan pembaharuan dalam dunia pendidikan.

\section{DAFTAR PUSTAKA}

Abidin, (2004). Evaluasi Pengajaran, Jakarta: UNP. 
Anitah W, Sri dkk (2017). Strategi Pembelajaran di SD, Tangerang Selatan: Universitas Terbuka.

Arsyad, Arsyad, \& Sulfemi, Wahyu Bagja. (2013). Pengaruh Persepsi Guru Tentang Kemampuan Manajerial Kepala Sekolah dan Kecerdasan Emosional Guru Terhadap Kinerja Guru (Studi Kasus Di SMK Muhammadiyah 6 Kabupaten Bogor). Fascho 2 (1), 1-9

Arsyad, Arsyad dan Sulfemi, Wahyu Bagja. (2018) Metode Role Playing Berbantu Media Audio Visual Pendidikan dalam Meningkatkan Belajar IPS. Jurnal Pendidikan Ilmu Pengetahuan Sosial Indonesia. 3 (2). 41 - 46

Daryanto (2015). Model Pembelajaran Inovatif, Yogyakarta: Gava Media.

Mulyati. (2015). Terampil Berbahasa Indonesia. Jakarta: Prenadamedia Group

Habiba, Riefka Iesna. (2017). Peningkatan Hasil Belajar Dengan Media Kartu Kwartet Dalam Keterampilan Menyusun Portofolio. Ilmu Pendidikan, 2 (1). 85-91.

Sudirman, Sudirman \& Sulfemi, Wahyu Bagja. (2010). Korelasi Antara Konsep Diri Guru dengan Profesionalisme Guru di SMA Negeri 1 Pamijahan Kabupaten Bogor. Edutecno 2 (2), 10-19

Sugiri, Sugiri \& Sulfemi, Wahyu Bagja. (2011). Pendidikan Multi Kultur di Sekolah Berbasis Keagamaan. Edutecno. 3 (2), 11-20

Suprihatin, Y., \& Sulfemi, WB. (2013). Kemampuan Menulis Deskripsi. Bogor : STKIP Muhammadiyah Bogor.

Suprijono, Agus. (2011). Cooperative Learning Teori dan Aplikasi PAIKEM. Yogyakarta: Pustaka Pelajar

Sanjaya, Wina. (2011) .Perencanaan dan Desain Sistem Pembelajaran, Jakarta: Kencana

Sadiman, (2012). Media pendidikan: pengertian, pengembangan, dan pemanfaatannya, Jakarta: PT Raja Grafindo Persada.

Makmun, Khairani (2014). Psikologi Belajar, Yogyakarta: Aswaja Pressindo.

Solchan, dkk. (2011). Pendidikan Bahasa Indonesia di SD. Tangerang Selatan: Universitas Terbuka

Sulfemi, Wahyu Bagja. (2015). Pengaruh Metode Pembelajaran Kontekstual dan Penggunaan Media Video Pendidikan Terhadap Hasil Belajar IPS. Edutecno $13(2), 1-10$.

Sulfemi, Wahyu Bagja dan Lestari, Ayu Hopilatul. (2017). Korelasi Kompetensi Pedagogik Guru dengan Prestasi Belajar Mata Pelajaran IPS Di SMP Muhammadiyah Pamijahan Kabupaten Bogor. Edutecno. 16 (1), 1-16

Sulfemi, Wahyu Bagja dan Abdul Qodir. (2017). Hubungan Kurikulum 2013 Dengan Motivasi Belajar Peserta Didik Di SMK Pelita Ciampea. Edutecno 17 (2), 18 
Sulfemi, Wahyu Bagja dan Hilga Minati. (2018). Meningkatkan Hasil Belajar Peserta Didik Kelas 3 SD Menggunakan Model Picture And Picture dan Media Gambar Seri. JPSD. 4 (2), 228- 242.

Sulfemi, Wahyu Bagja dan Supriyadi, Dede. (2018). Pengaruh Kemampuan Pedagogik Guru dengan Hasil Belajar IPS. Edutecno 17 (1), 1-10.

Sulfemi, Wahyu Bagja. (2018). Hubungan Motivasi Belajar Dengan Hasil Belajar IPS Di SMP Kabupaten Bogor. Edutecno 18 (2), 1-8.

Sulfemi, Wahyu Bagja dan Desmiati, Zulaicha. (2018). Model Pembelajaran Missouri Mathematics Project Berbantu Media Relief Experience dalam Meningkatkan Hasil Belajar Siswa. Jurnal Pendas Mahakam . 3 (3), 232245 .

Sulfemi, Wahyu Bagja dan Setianingsih. (2018), Penggunaan Tames Games Tournament (TGT) Dengan Media Kartu Dalam Meningkatkan Hasil Belajar. Journal of Komodo Science Education (JKSE. 1 (1), 1-14

Sulfemi, Wahyu Bagja dan Nurhasanah. (2018). Penggunaan Metode Demontrasi dan Media Audio Visual Dalam Meningkatkan Hasil Belajar Peserta Didik Mata Pelajaran IPS. Jurnal Pendas Mahakam. 3 (2). 151-158

Sulfemi, Wahyu Bagja. (2018). Pengaruh Disiplin Ibadah Sholat, Lingkungan Sekolah, dan Intelegensi Terhadap Hasil Belajar Peserta Didik Mata Pelajaran Pendidikan Agama Islam. Edukasi: Jurnal Penelitian Pendidikan Agama dan Keagamaan. 16 (2), 166-178

Sulfemi, Wahyu Bagja. (2018). Manajemen Pendidikan Berbasis Multi Budaya. Bogor : STKIP Muhammadiyah Bogor .

Sulfemi, Wahyu Bagja., \& Yuliana, Desi. (2019). Penerapan Model Pembelajaran Discovery Learning Meningkatkan Motivasi dan Hasil Belajar Pendidikan Kewarganegaraan. Jurnal Rontal Keilmuan Pancasila dan Kewarganegaraan. 5 (1), 17-30.

Sulfemi, W. B. (2019). Modul Pembelajaran Perundang-Undangan Pendidikan. Bogor : STKIP Muhammadiyah Bogor

Sulfemi, Wahyu Bagja. (2019). Model Pembelajaran Kooperatif Mind Mapping Berbantu Audio Visual Dalam Meningkatkan Minat, Motivasi dan Hasil Belajar IPS. Jurnal Pendidikan Ilmu Pengetahuan Sosial Indonesia (PIPSI). 4 (1), $13-19$.

Yusfiriadi, Yusfiriadi, \& Sulfemi, Wahyu Bagja. (2011). Pemberdayaan Unit Produksi Melalui Pendekatan Manajemen Stratejik di SMK Pertiwi Kabupaten Bogor. Edutecno. 3 (1), 1-10.

Zuhairini, dkk, (2001). Metodik Khusus Pendidikan Agama. Malang FAK. Tarbiyah IAIN Sunan Ampel.

Zaini, Hisyam (2008). Strategi Pembelajaran Aktif, Yogyakarta: Insan Mandiri. 
Zahroh, Aminatul.(2015). Membangun Kualitas Pembelajaran Melalui Dimens Profesionlisme Guru. Bandung:Yrama Widya. 